\title{
FAKTOR-FAKTOR YANG MEMPENGARUHI MINAT MASYARAKAT BAWEAN DALAM MEMILIH BANK SYARIAH
}

\author{
Nur Salis', Nihayatu Aslamatis Solekah ${ }^{2}$ \\ 1,2 Universitas Islam Negeri Maulana Malik Ibrahim Malang, Indonesia
}

$\triangle$ Corresponding Author:

Nama Penulis: Nihayatu Aslamatis Solekah

E-mail: Aslamatiss_1@pbs.uin-malang.ac.id

\section{Abstract}

Indonesia Sharia banks need to be developed because they have comprehensive advantages over conventional banking. To reach services to the community, it is necessary to expand in developing a network of Sharia Bank offices. Therefore there must be an effort from Sharia banking increases public interest in Sharia Banks so that it can be developed. The purpose of this study is to find out what factors influence the interest of the Bawean community in choosing a Sharia Partner Bank and to find out what the most dominant factors influence the interest of Bawean community in choosing Sharia Partner Bank. This study uses descriptive quantitative method. The population of this study is 165 samples of Bawean community and the sampling technique used purposive sampling. The data analysis technique uses Partial Least Squares (PLS) analysis which is a Structural Equation Modelling (SEM). The result of this study indicate that the marketing mix factor, internal individual consumers and external individual consumers influence the interest of the Bawean community in choosing Sharia Partner Banks. While the marketing mix factor is the most dominant factor affecting the interest of the Bawean community in choosing Sharia Partner Banks.

Key words: Sharia Banking; Marketing Mix; Internal Individual Consumers; External Individual Consumers.

\section{Abstrak}

Di Indonesia Bank Syariah perlu dikembangkan karena memiliki keunggulan komprehensif dibandingkan perbankan konvensional. Untuk menjangkau pelayanan pada masyarakat maka perlu melakukan perluasan dalam mengembangkan jaringan kantor Bank Syariah. Oleh karena itu harus ada upaya dari perbankan syariah, supaya minat masyarakat terhadap bank syariah semakin meningkat sehingga bank syariah bisa lebih berkembang. Tujuan penelitian ini untuk mengetahui faktor-faktor apa saja yang mempengaruhi minat masyarakat Bawean dalam memilih Bank Mitra Syariah dan untuk mengetahui faktor apa yang paling dominan mempengaruhi minat masyarakat Bawean dalam memilih Bank Mitra Syariah. Penelitian ini menggunakan metode kuantitatif deskriptif. Populasi dari penelitian ini adalah seluruh masyarakat Bawean dengan 165 sampel dan teknik pengambilan sampel menggunakan purposive sampling. Teknik analisis data menggunakan Analisis Partial Least Squares (PLS) yang merupakan persamaan Struktural Equation Modelling (SEM). Hasil Penelitian ini menunjukkan bahwa faktor marketing mix, internal individu konsumen, dan 
eksternal individu konsumen mempengaruhi minat masyarakat Bawean dalam memilih Bank Mitra Syariah. Sedangkan faktor marketing mix merupakan faktor yang paling dominan mempengaruhi minat masyarakat Bawean dalam memilih Bank Mitra Syariah

Kata kunci: Perbankan Syariah; Marketing Mix; Internal Individu Konsumen; Eksternal Individu Konsumen.

\section{PENDAHULUAN}

Bank Syariah mulai berkembang sangat pesat dengan lahirnya institusi keuangan internasional yang diberinama Islamic Development Bank (IDB) yang disahkan di Jeddah pada tangggal 20 Oktober tahun 1973. Tujuannya adalah untuk mempromosikan perkembangan ekonomi dan sosial dari Negara-negara anggota dan masyarkat muslim pada khususnya (Rivai \& Arivin, 2010). Bank Syariah yang pertama kali muncul di Indonesia yakni dengan munculnya PT Bank Muamalat Indonesia (BMI). BMI tersebut berdiri pada bulan November tahun 1991 yang secara murni menerapkan prinsip syariah berupa prinsip bagi hasil dalam operasional usahanya, dan mulai beroperasi pada bulan Mei tahun 1992 (Rivai \& Arivin, 2010).

Di Indonesia Bank Syariah perlu dikembangkan karena memiliki keunggulan komprehensif dibandingkan perbankan konvensional. Untuk menjangkau pelayanan pada masyarakat maka perlu melakukan perluasan dalam mengembangkan jaringan kantor Bank Syariah. Kinerja Bank Syariah harus bisa bersaing dengan bank konvensional. Oleh karena itu harus ada upaya dari perbankan syariah, supaya minat masyarakat terhadap bank syariah semakin meningkat sehingga bank syariah bisa lebih berkembang. Bank Syariah mempunyai tingkat kesehatan yang sesuai dengan standard yang telah ditetapkan oleh Bank Indonesia (Fortrania \& Oktaviana, 2015).

Strategi pemasaran efektif mengubah dan memelihara perilaku konsumen (Peter, et al., 2013). Pemasaran yang baik membutuh Transparency, Accountability, Responsibility, Indepandency dan Fairness yang diatur pada prinsip good corporate governance (GCG)(Mufidah \& Purnamasari, 2018). Konsep bauran pemasaran (marketing mix) terdapat empat P (4 P) yaitu: produk (product), harga (price), lokasi (place), promosi (promotion) (Blut, Teller, \& Floh, 2018). Sedangkan Boom dan Bitner berpendapat dalam bisnis jasa, bauran pemasaran selain 4P ada tambahan 3 $\mathrm{P}$, yaitu orang (people), bukti fisik (physical evidence), dan proses (process) (Kasmir, 2008). Menurut Engel et al (1995) faktor-faktor yang mempengaruhi prilaku konsumen adalah faktor kebudayaan, sosial, personal, keluarga, dan situasi (Simamora, 2004). Menurut Nitisusastro (2012) unsur- 
unsur faktor yang mempengaruhi prilaku konsumen terbagi menjadi dua, yaitu faktor internal konsumen, dan faktor eksternal konsumen.

Dari hasil penelitian-penelitian terdahulu yang sudah dilakukan khususnya hasil penelitian (Nelvi, 2015), (Fitriyani, 2016) dan (Utomo, 2014) masih terdapat kontradiksi. Kontradiksi yang ada pada tiga penelitian tersebut yaitu terdapat pada faktor lokasi dan promosi. Pada penelitian Utomo dua faktor tersebut tidak berpengaruh secara signifikan, akan tetapi pada penelitiannya Nelvi dua faktor tersebut berpengaruh secara signifikan, sedangkan pada penelitian Fitriyani dua faktor tersebut tidak dipakai. Adanya kotradiksi tersebut maka terdapat research gap (celah penelitian) yang menjadikan daya tarik bagi peniliti untuk melakukan penelitian lebih lanjut. Berawal dari kondisi diatas, merupakan suatu hal yang menarik untuk ditelaah, diteliti dan dicermati faktor apa saja yang mempengaruhi keputusan masyarakat Bawean untuk menggunakan bank syariah.

Studi ini memilih Bank Mitra Syariah karena bank tersebut merupakan salah satu jenis BPRS yang ada di pulau Bawean. Bank Mitra Syariah memiliki fungsi sebagaimana layaknya bank-bank lain yang menawarkan produkproduk perbankan syariah. Bank mitra syariah masih tergolong sangat baru sekali karena beroperasi baru 1 tahun lebih. Bank mitra syariah menjadi salah satu alternatif alat intermediasi untuk menabung dan meminjam dengan prinsip syariah bagi masyarakat di pulau Bawean.

Bawean adalah sebuah pulau dengan luas 200 kilomiter persegi. Pulau Bawean secara administratif merupakan bagian dari kabupaten Gresik, Jawa Timur dan terdiri dua kecamatan yaitu Sangkapura dan Tambak dengan jumlah penduduknya sebanyak 114.662. Masyarakat Bawean mempunyai keunikan budaya yang kemungkinan besar tidak dimiliki oleh masyarakat lain. Keunikannya yaitu: Pertama, (Asyhar, 2016) menyatakan masyarakat Bawean khususnya laki-laki mempunyai tradisi merantau ke jawa bahkan ke luar negeri seperti ke Malaysia dan Singapura. Kedua, menurut Asyhar (2016) masyarakat Bawean mempunyai hobi mengoleksi emas. Ketika menghadiri acara resepsian atau pergi kepasar biasanya para ibu-ibu memakainya secara berlebihan. Ketiga, masyarakat Bawean mempunyai kebiasaan nongkrong di dhurung atau gazebo di desanya masing-masing. Selain nongkrong tempat tersbebut bisa digunakan sebagai ajang silaturrahmi oleh masyarakat setempat (http://rusabawean.com/). Keempat, Manurut Asyhar (2016) berdasarkan laporan statistik masyarakat Bawean tercatat $100 \%$ beragama islam dan tempat ibadah yang tersedia di pulau Bawean $100 \%$ untuk umat Islam seperti masjid, musola atau langgar.

Diharapkan faktor-faktor yang akan dipakai dalam penelitian ini dapat memberikan kepuasan dan kenyamanan bagi nasabah, selain itu bank tersebut juga harus mampu membaca peluang agar bisa menganalisa 
kebutuhan dan harapan pelanggan yang berada di pulau Bawean. Sehingga bank mitra syariah menjadi satu-satunya BPRS yang memiliki tingkat kepercayaan nasabah yang tinggi di pulau Bawean. Berdasarkan hasil uraian diatas, maka penelitian ini diajukan untuk mengetahui kreteria masyarakat dalam memutuskan untuk menjadi nasabah pada bank syariah. Maka penulis tertarik untuk melakukan penelitian "Faktor-Faktor yang Mempengaruhi Minat Masyarakat Bawean dalam memilih Bank Syariah)”.

\section{KAJIAN PUSTAKA}

\section{Faktor marketing mix}

\section{Produk}

Menurut Kasmir (2008) Produk adalah sesuatu yang dapat memberikan manfaat baik dalam hal memenuhi kebutuhan sehari-hari atau sesuatu yang ingin dimiliki oleh konsumen. Sedangkan menurut Kotler produk adalah segala sesuatu yang ditawarkan kepada pasar untuk untuk mendapatkan perhatian dibeli, untuk dipakai sehari-hari dalam memenuhi kebutuhan.

\section{Harga}

Penentuan harga dalam kegiatan pemasaran merupakan salah satu aspek yang penting, karena laku atau tidaknya produk dan jasa perbankan bisa dilihat dari aspek harga. Menurut Engel et al, (1994) ketika akan menetapkan harga tidak boleh dilakukan secara kebetulan. Penelitian yang ahli dapat membuktikan kebenaran harga konsumen.

\section{Lokasi}

Lokasi adalah tempat dimana diperjual belikannya produk cabang bank dan pusat pengendalian perbankan. Dalam menentukan lokasi suatu suatu cabang bank merupakan salah satu kebijakan yang sangat penting. Bank yang lokasinya terletak secara strategis sangat memudahkan nasabah dalam berhubungan dengan bank (Kasmir, 2008).

\section{Promosi}

Secara garis besar ada empat macam sarana promosi yang digunakan dalam perbankan yaitu: 1) Priklanan (advertising), 2) Promosi penjualan, 3) Publisitas (Publicity), 4) Penjualan pribadi (personal selling).

\section{Pegawai (People)}

Pegawai berfungsi sebagai service provider sangat mempengaruhi kualitas jasa yang diberikan. Keputusan dalam people untuk mencapai kualitas berhubungan dengan seleksi, training, memotivasi, dan manajemen sumber daya manusia. Pentingnya people dalam memberikan pelayanan berkualitas berkaitan dengan internal marketing. 


\section{Bukti fisik (Physical evidence)}

Bukti fisik merupakan lingkungan fisik tempat jasa yang diciptakan dan langsung berintraksi dengan pelanggan. Dua tipe bukti fisik, yaitu: Bukti penting dan bukti perifer.

\section{Proses (process)}

Proses merupakan gabungan semua aktivitas, umumnya terdiri atas prosedur, jadwal pekerjaan, mekanisme, dan hal-hal rutin sampai jasa dihasilkan dan disampaikan kepada pelanggan.

\section{Faktor Internal Individu Konsumen}

\section{Persepsi (Preseption)}

Menurut Schiffman dan Kanuk (2008) presepsi adalah proses dimana seorang individu untuk menyeleksi, mengorganisasi, dan mengartikan stimulus menjadi sebuah makna yang koheren dengan semua kejadian di dunia.

\section{Kepribadian (Personality)}

Schiffman dan Kanuk (2008) mendifinisikan kepribadian sebagai ciriciri kejiwaan pada diri sendiri yang menentukan dan mencerminkan bagaimana seseorang merespon dalam lingkungannya.

\section{Pembelajaran (Learning)}

Pembelajaran adalah langkah-langkah untuk memperoleh pengetahuan dan pengalaman dari hasil yang diperoleh dapat memberikan bekal untuk melakukan tindakan dimasa yang depan jika berhadapan dengan situasi yang sama (Nitisusastro, 2012).

\section{Motivasi (Motivation)}

Motivasi merupakan dorongan dari dalam diri individu seseorang dan memaksa dia untuk berbuat. Dorongan ini didapatkan dari tekanan yang timbul akibat dari satu kebutuhan yang tidak terpenuhi. Arah motivasi bisa positif atau negatif. Dapat merasakan adanya tenaga pendorong kearah atau menghindar obyek atau keadaan tertentu (Schiffman \& Kanuk, 2008).

\section{Sikap (Attitude)}

Sikap adalah suatu keadaan pada diri seseorang untuk berprilaku suka atau tidak suka ketika bertemu pada satu situasi atau kejadian. Suatu kejadian yang mudah diterima oleh akal sehat biasanya bersifat universal. Universal adalah sebuah situasi dan keadaan manusia dari belahan bumi manapun (Purboyo \& Huda, 2017).

\section{Faktor Eksternal Individu Konsumen}

\section{Budaya}

Unsur-unsur budaya meliputi bahasa, pengetahuan, hukum, agama, teknologi, dan lain sebagainya. Budaya dan sub budaya berpengaruh sangat 
kuat pada sikap dan prilaku penduduk. Budaya dan nilai-nilainya diteruskan dari pertama kegenerasi selanjutnya (Nitisusastro, 2012).

\section{Status sosial}

Status sosial diartikan sebagai satu rangkaian tingkatan posisi sosial, dimana setiap anggota dari tingkatan menempati posisinya, atau sejumlah kelompok yang membagi-bagi kelompoknya dalam beberapa strata tingkatan. Status sosial secara tidak langsung mempengaruhi gaya hidup masyarakat. Faktor pembeda yang paling menonjol dalam kelompok masyarakat adalah tingkat pendidikan, jenis pekerjaan, dan tingkat penghasilan (Nitisusastro, 2012).

\section{Referensi kelompok}

Referensi kelompok yaitu seorang tokoh atau satu kelompok orang tertentu dalam masyarakat yang dijadikan acuan atau rujukan oleh seseorang atau lebih anggota masyarakat dalam membentuk pandangan tentang nilai sikap atau sebagai pedoman berprilaku yang memiliki ciri-ciri khusus (Sartono, Susanti, \& Lamidi, 2018).

\section{Keluarga}

Definisi dari anggota keluarga adalah kelompok yang terdiri dari dua orang atau lebih yang berhubungan melalui darah, perkawinan, atau adopsi dan tinggal bersama. Perusahaan termasuk organisasi yang terbentuk mencapai fungsi tertentu yang lebih efektif yang dibandingkan dengan individu yang hidup sendiri (Engel, Blackwell, \& Miniard , 1994). Dari penjelasan teori diatas maka dalam penelitian ini dapat di gambarkan kerangka konseptual sebagaimana Gambar 1 dibawah ini

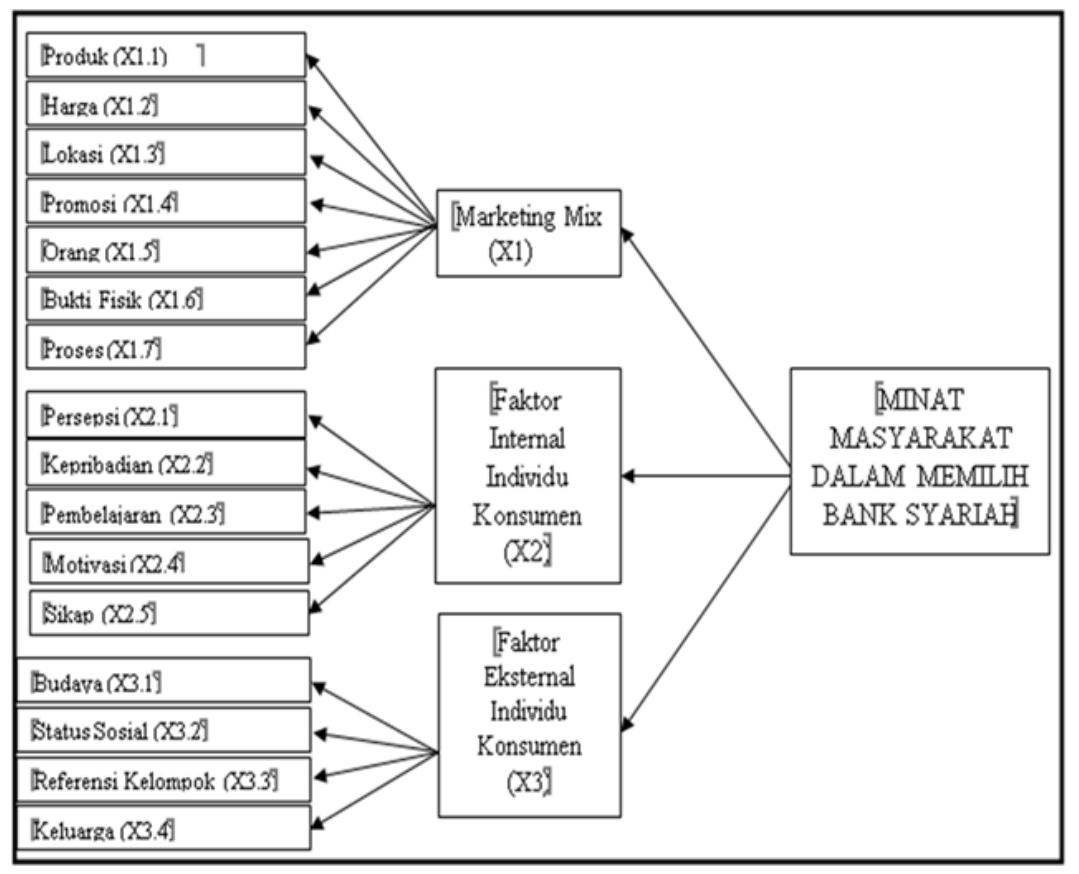

Gambar 1. Kerangka Konseptual

Sumber : (Data diolah 2018) 


\section{METODE}

Metode yang akan dipakai pada penelitian ini berdasarkan rumusan masalah dan tujuan yang ingin dicapai maka menggunakan metode penelitian kuantitatif. Dalam penelitian ini menetapkan lokasi yang dipilih yaitu Bank Mitra Syariah Cabang Bawean. Populasi dalam penelitian ini adalah seluruh masyarakat pulau Bawean. Untuk menentukan ukuran sampel apabila populasi tidak diketahui berapa jumlahnya, maka bisa menggunakan teori Malhotra dalam penelitiannya (Jannah, 2010) dengan rumus paling sedikit lima kali dari jumlah item pertanyaan. Dalam penelitian ini terdapat 33 item pertanyaan, sehingga ukuran penelitian ini adalah 33 item x $5=165$ sampel. Jadi, jumlah sampel yang diambil sebanyak 165 sampel.

Data yang digunakan pada penelitian ini yaitu data primer dan skunder. Teknik pengumpulan data menggunakan metode wawancara, observasi lapangan, dokumentasi, dan kuisioner. Skala yang dipakai yaitu skala likert. Penelitian ini menggunakan teknik purposive sampling yaitu pengambilan sampel dipilih berdasarkan kriteria yang sudah ditetapkan. Kriteria yang digunakan dalam teknik pengambilan sampel yaitu:

1. Masyarakat yang sudah berumur lebih dari $>17$ tahun

2. Masyarakat yang mempunyai pengetahuan bahwasanya bank syariah itu menggunakan prinsip syariah.

3. Masyarakat yang mempunyai minat untuk menjadi nasabah bank syariah

Analisis yang digunakan pada penelitian ini menggunakan Analisis Partial Least Squares (PLS) yang merupakan persamaan Struktural Equation Modelling (SEM).

\section{HASIL DAN PEMBAHASAN}

\section{Model Pengukuran (Outer Model)}

Rekapitulasi hasil evaluasi validitas dan reliabilitas dapat dilihat pada Tabel 1. Dalam hal ini peneliti mempertimbangkan untuk mengeluarkan item atau faktor yang memiliki nilai bobot faktor yang rendah atau tidak mencapai standar validitas yang baik, yaitu mereduksi atau menyederhanakan pengukuran Indikator dengan mengeluarkan item yang diberi tanda merah hingga hasil pengujian ulang menghasilkan nilai bobot faktor, AVE dan CR yang sesuai dengan standar kriteria evaluasi model pengukuran. Secara detail dijabarkan hasil analisis pada Tabel 2. sebagai berikut: 
Nur Salis: Faktor yang Mempengaruhi Masyarakat Bawean

Tabel 1. Evaluasi Model Pengukuran Tahap 1(1st Order Outer Model) Sebelum Eliminasi

\begin{tabular}{|c|c|c|c|c|c|c|c|c|}
\hline \multirow{3}{*}{$\begin{array}{l}\text { Variabel } \\
\text { Laten }\end{array}$} & \multirow{3}{*}{$\begin{array}{l}\text { Variabel } \\
\text { Teramati }\end{array}$} & \multicolumn{5}{|c|}{ Validitas Konvergen } & \multirow{2}{*}{\multicolumn{2}{|c|}{$\begin{array}{c}\text { Composite Reliability } \\
\text { (CR }>0,7)\end{array}$}} \\
\hline & & \multicolumn{2}{|c|}{ (LF > 0,5 =Valid) } & \multirow{2}{*}{ 裉 } & \multicolumn{2}{|c|}{ (AVE $>0,5=$ Valid) } & & \\
\hline & & Loading & $\begin{array}{l}\text { Kesim- } \\
\text { pulan }\end{array}$ & & AVE & $\begin{array}{l}\text { Kesim- } \\
\text { pulan }\end{array}$ & CR & Keterangan \\
\hline \multirow{7}{*}{$\begin{array}{l}\text { Marketing } \\
\text { Mix (X1) }\end{array}$} & $\mathrm{X} 1.1$ & 0,799 & Valid & 2 & \multirow{7}{*}{0,562} & \multirow{7}{*}{ Valid } & \multirow{7}{*}{0,899} & \multirow{7}{*}{ Reliabel } \\
\hline & $\mathrm{X} 1.2$ & 0,712 & Valid & 6 & & & & \\
\hline & $\mathrm{X} 1.3$ & 0,738 & Valid & 5 & & & & \\
\hline & $\mathrm{X} 1.4$ & 0,769 & Valid & 4 & & & & \\
\hline & $\mathrm{X} 1.5$ & 0,792 & Valid & 3 & & & & \\
\hline & X1.6 & 0,618 & Valid & 7 & & & & \\
\hline & $\mathrm{X} 1.7$ & 0,801 & Valid & 1 & & & & \\
\hline \multirow{5}{*}{$\begin{array}{c}\text { Faktor } \\
\text { Internal } \\
\text { Individu } \\
\text { Konsumen } \\
\text { (X2) }\end{array}$} & $\mathrm{X} 2.1$ & 0,795 & Valid & 2 & \multirow{5}{*}{0,491} & \multirow{5}{*}{ Tidak Valid } & \multirow{5}{*}{0,821} & \multirow{5}{*}{ Reliabel } \\
\hline & $\mathrm{X} 2.2$ & 0,608 & Valid & 4 & & & & \\
\hline & $\mathrm{X} 2.3$ & 0,784 & Valid & 3 & & & & \\
\hline & X2.4 & 0,814 & Valid & 1 & & & & \\
\hline & $\mathrm{X} 2.5$ & 0,420 & $\begin{array}{l}\text { Tidak } \\
\text { Valid }\end{array}$ & 5 & & & & \\
\hline \multirow{4}{*}{$\begin{array}{c}\text { Faktor } \\
\text { Eksternal } \\
\text { Individu } \\
\text { Konsumen } \\
\text { (X3) }\end{array}$} & X3.1 & 0,779 & Valid & 3 & \multirow{4}{*}{0,564} & \multirow{4}{*}{ Valid } & \multirow{4}{*}{0,832} & \multirow{4}{*}{ Reliabel } \\
\hline & $\mathrm{X} 3.2$ & 0,835 & Valid & 2 & & & & \\
\hline & $\mathrm{X} 3.3$ & 0,852 & Valid & 1 & & & & \\
\hline & X3.4 & 0,475 & $\begin{array}{l}\text { Tidak } \\
\text { Valid }\end{array}$ & 4 & & & & \\
\hline
\end{tabular}

Sumber: Hasil Analisis (2018)

Tabel 2. First Order Outer Model pada Variabel Marketing Mix (X1) Setelah Eleminasi

\begin{tabular}{|c|c|c|c|c|c|c|c|c|}
\hline \multirow{3}{*}{$\begin{array}{l}\text { Variabel } \\
\text { Laten }\end{array}$} & \multirow{3}{*}{$\begin{array}{l}\text { Variabel } \\
\text { Teramati }\end{array}$} & \multicolumn{5}{|c|}{ Validitas Konvergen } & \multirow{2}{*}{\multicolumn{2}{|c|}{$\begin{array}{c}\text { Composite } \\
\text { Reliability (CR > } \\
0,7)\end{array}$}} \\
\hline & & \multicolumn{2}{|c|}{ (LF $>0,5=$ Valid $)$} & \multirow{2}{*}{ 里 } & \multicolumn{2}{|c|}{ (AVE $>0,5=$ Valid $)$} & & \\
\hline & & $\begin{array}{l}\text { Loading } \\
\text { Factor }\end{array}$ & $\begin{array}{l}\text { Kesim- } \\
\text { pulan }\end{array}$ & & AVE & $\begin{array}{c}\text { Kesim- } \\
\text { pulan }\end{array}$ & CR & Keterangan \\
\hline \multirow{7}{*}{$\begin{array}{l}\text { Marketing } \\
\text { Mix (X1) }\end{array}$} & $\begin{array}{c}\text { Proses } \\
(\mathrm{X} 1.7)\end{array}$ & 0,801 & Valid & 1 & \multirow{7}{*}{0,562} & \multirow{7}{*}{ Valid } & \multirow{7}{*}{0,899} & \multirow{7}{*}{ Reliabel } \\
\hline & $\begin{array}{c}\text { Produk } \\
\text { (X1.1) }\end{array}$ & 0,799 & Valid & 2 & & & & \\
\hline & $\begin{array}{l}\text { Orang } \\
\text { (X1.5) }\end{array}$ & 0,792 & Valid & 3 & & & & \\
\hline & $\begin{array}{c}\text { Promosi } \\
(\mathrm{X} 1.4)\end{array}$ & 0,769 & Valid & 4 & & & & \\
\hline & $\begin{array}{l}\text { Lokasi } \\
\text { (X1.3) }\end{array}$ & 0,738 & Valid & 5 & & & & \\
\hline & $\begin{array}{l}\text { Harga } \\
(\mathrm{X} 1.2)\end{array}$ & 0,712 & Valid & 6 & & & & \\
\hline & $\begin{array}{c}\text { Bukti Fisik } \\
\text { (X1.6) }\end{array}$ & 0,618 & Valid & 7 & & & & \\
\hline
\end{tabular}

Sumber: Hasil Analisis (2018) 
Berdasarkan Tabel 2. dapat diketahui bahwa seluruh nilai Loading factor pada Marketing Mix (X1) $\geq 0,50$, dan nilai nilai AVE 0,562 > 0,50 (Valid). Dengan demikian dapat disimpulkan bahwa validitas semua variabelvariabel manifes terhadap variabel latennya adalah baik. Sedangkan dari hasil perhitungan reliabilitas menunjukkan bahwa Marketing Mix (X1) memiliki nilai Composite Reliability (CR) 0,899 $\geq 0,70$ (Reliabel), dengan demikian dapat disimpulkan bahwa memiliki reliabilitas yang baik.

Tabel 3. menjelaskan bahwa seluruh nilai Loading factor pada Faktor Internal Individu Konsumen (X2) $\geq 0,50$, dan nilai nilai AVE 0,586 > 0,50 (Valid). Dengan demikian dapat disimpulkan bahwa validitas semua variabelvariabel manifes terhadap variabel latennya adalah baik. Sedangkan dari hasil perhitungan reliabilitas menunjukkan bahwa Faktor Internal Individu Konsumen (X2) memiliki nilai Composite Reliability (CR) 0,848 $\geq 0,70$ (Reliabel), dengan demikian dapat disimpulkan bahwa memiliki reliabilitas yang baik. Secara detail, guna mengetahui faktor kunci yang mulai dari yang paling dominan dalam memberikan kontribusi terhadap konstruk laten dijelaskan sebagai berikut.

Tabel 4. menunjukkan bahwa seluruh nilai Loading factor pada Faktor Eksternal Individu Konsumen (X3) $\geq 0,50$, dan nilai nilai AVE 0,692 > 0,50 (Valid). Sedangkan dari hasil perhitungan reliabilitas menunjukkan bahwa Faktor Eksternal Individu Konsumen (X3) memiliki nilai Composite Reliability (CR) 0,871 $\geq 0,70$ (Reliabel).

Tabel 5 menjelaskan bahwa semua nilai Loading $\geq 0,500$. Dengan demikian dapat disimpulkan bahwa validitas semua variabel-variabel manifes terhadap variabel latennya adalah baik. Secara ringkas semua faktorfaktor yang valid bisa dilihat pada Gambar 2 .

Tabel 3. First Order Outer Model pada Variabel Faktor Internal Individu Konsumen (X2)

\begin{tabular}{|c|c|c|c|c|c|c|c|c|}
\hline \multirow{4}{*}{$\begin{array}{c}\text { Variabel } \\
\text { Laten }\end{array}$} & \multirow{4}{*}{$\begin{array}{l}\text { Variabel } \\
\text { Teramati }\end{array}$} & \multirow{2}{*}{\multicolumn{5}{|c|}{ Validitas Konvergen }} & & \\
\hline & & & & & & & \multirow{2}{*}{\multicolumn{2}{|c|}{$\begin{array}{c}\text { Composite } \\
\text { Reliability (CR > } \\
0,7)\end{array}$}} \\
\hline & & \multicolumn{2}{|c|}{ (LF $>0,5=$ Valid $)$} & \multirow{2}{*}{ 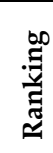 } & \multicolumn{2}{|c|}{ (AVE $>0,5=$ Valid) } & & \\
\hline & & $\begin{array}{c}\text { Loading } \\
\text { Factor }\end{array}$ & $\begin{array}{c}\text { Kesim- } \\
\text { pulan }\end{array}$ & & AVE & $\begin{array}{c}\text { Kesim- } \\
\text { pulan }\end{array}$ & CR & Keterangan \\
\hline \multirow{4}{*}{$\begin{array}{c}\text { Faktor } \\
\text { Internal } \\
\text { Individu } \\
\text { Konsumen } \\
\text { (X2) }\end{array}$} & $\begin{array}{c}\text { Persepsi } \\
(\mathrm{X} 2.1)\end{array}$ & 0,814 & Valid & 1 & \multirow{4}{*}{0,586} & \multirow{4}{*}{ Valid } & \multirow{4}{*}{0,848} & \multirow{4}{*}{ Reliabel } \\
\hline & $\begin{array}{c}\text { Motivasi } \\
(X 2.4)\end{array}$ & 0,802 & Valid & 2 & & & & \\
\hline & $\begin{array}{c}\text { Pembelajaran } \\
(\mathrm{X} 2.3) \\
\end{array}$ & 0,800 & Valid & 3 & & & & \\
\hline & $\begin{array}{c}\text { Kepribadian } \\
(\mathrm{X} 2.2)\end{array}$ & 0,629 & Valid & 4 & & & & \\
\hline
\end{tabular}

Sumber: Hasil Analisis (2018) 
Nur Salis: Faktor yang Mempengaruhi Masyarakat Bawean

Tabel 4. First Order Outer Model pada Variabel Faktor Eksternal Individu Konsumen (X3)

\begin{tabular}{|c|c|c|c|c|c|c|c|c|}
\hline \multirow{3}{*}{$\begin{array}{l}\text { Variabel } \\
\text { Laten }\end{array}$} & \multirow{3}{*}{$\begin{array}{l}\text { Variabel } \\
\text { Teramati }\end{array}$} & \multicolumn{5}{|c|}{ Validitas Konvergen } & \multirow{2}{*}{\multicolumn{2}{|c|}{$\begin{array}{c}\text { Composite } \\
\text { Reliability }(C R>0,7)\end{array}$}} \\
\hline & & \multicolumn{2}{|c|}{ (LF $>0,5=$ Valid $)$} & \multirow{2}{*}{ 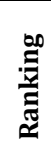 } & \multicolumn{2}{|c|}{ (AVE $>0,5=$ Valid) } & & \\
\hline & & $\begin{array}{l}\text { Loading } \\
\text { Factor }\end{array}$ & $\begin{array}{c}\text { Kesim- } \\
\text { pulan }\end{array}$ & & AVE & $\begin{array}{c}\text { Kesim- } \\
\text { pulan }\end{array}$ & CR & Keterangan \\
\hline \multirow{3}{*}{$\begin{array}{c}\text { Faktor } \\
\text { Eksternal } \\
\text { Individu } \\
\text { Konsumen } \\
\text { (X3) }\end{array}$} & $\begin{array}{c}\text { Referensi } \\
\text { Kelomok } \\
\text { (X3.3) }\end{array}$ & 0,848 & Valid & 1 & \multirow{3}{*}{0,692} & \multirow{3}{*}{ Valid } & \multirow{3}{*}{0,871} & \multirow{3}{*}{ Reliabel } \\
\hline & $\begin{array}{c}\text { Budaya } \\
\text { (X3.1) }\end{array}$ & 0,800 & Valid & 3 & & & & \\
\hline & $\begin{array}{l}\text { Status } \\
\text { Sosial } \\
\text { (X3.2) }\end{array}$ & 0,847 & Valid & 2 & & & & \\
\hline
\end{tabular}

Sumber: Hasil Analisis (2018)

Tabel 5. Evaluasi Model Pengukuran Tahap 2 (2nd Order Outer Model)

\begin{tabular}{|c|c|c|c|c|c|}
\hline Variabel Latent & Variabel Manifest & Loading & $\begin{array}{l}\text { Rule of } \\
\text { Thumb }\end{array}$ & Ket & Ranking \\
\hline \multirow{3}{*}{$\begin{array}{c}\text { Minat Masyarakat } \\
\text { Dalam Memilih Bank } \\
\text { Syariah }(\mathrm{X})\end{array}$} & Marketing Mix (X1) & 0,938 & 0,500 & Valid & 1 \\
\hline & $\begin{array}{l}\text { Faktor Internal Individu Konsumen } \\
\text { (X2) }\end{array}$ & 0,849 & 0,500 & Valid & 2 \\
\hline & 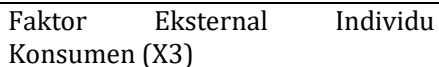 & 0,770 & 0,500 & Valid & 3 \\
\hline
\end{tabular}

Sumber: Hasil Analisis (2018)

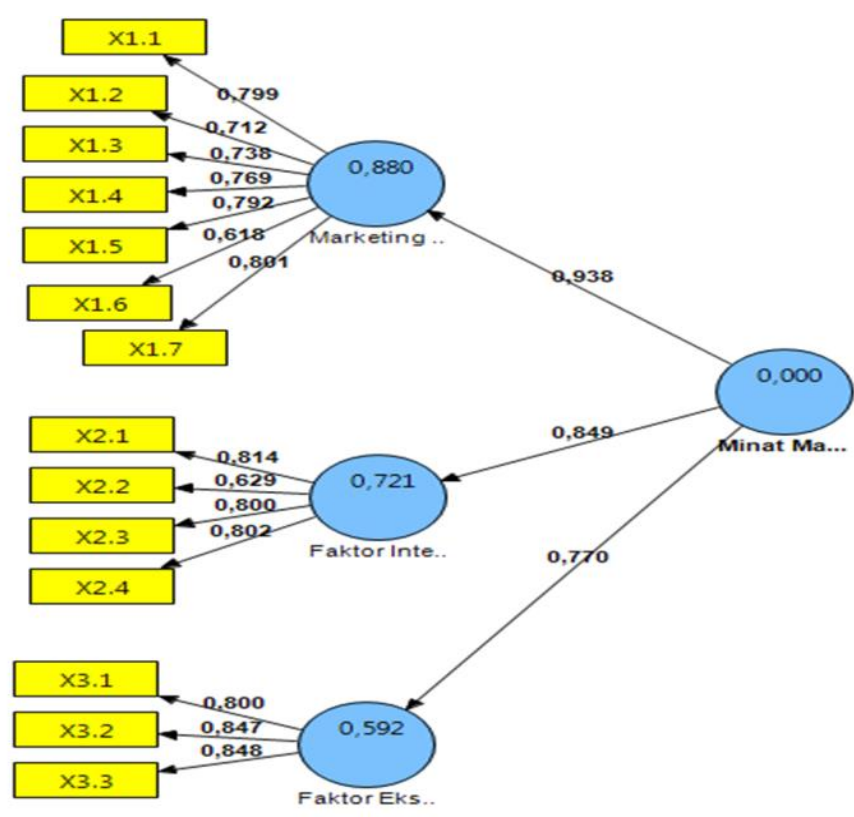

Gambar 2. Loading Factor Untuk Semua Variabel

Sumber : Data Diolah 2018 


\section{Faktor Marketing Mix yang Mempengaruhi Minat Masyarakat Bawean dalam Memilih Bank Mitra Syariah}

Berdasarkan hasil penelitian yang telah dilakukan secara struktural indikator Proses merupakan indikator yang dapat memberikan kontribusi terhadap minat masyarakat Bawean dalam memilih Bank Mitra Syariah. Proses yang dilakukan oleh bank mitra syariah dalam melakukan transaksi sangat baik, dimana pegawai tidak melakukan transaksi didalam kantor akan tetapi juga meluangkan waktunya untuk mendatangi nasabah dan melakukan transasksi penarikan simpanan kepada nasabah dimana nasabah itu berada, sehingga hal tersebut dapat mempermudah nasabah untuk melakukan simpanan tanpa harus datang langsung kekantornya.

Sedangkan untuk indikator produk merupakan indikator yang dapat memberikan kontribusi terhadap minat masyarakat Bawean dalam memilih Bank Mitra Syariah. Penentuan produk yang dapat menyesuaikan lingkungan yang ada dan memenuhi keinginan mayarakat besar kemungkinan jumlah nasabah yang menabung di Bank Mitra Syariah akan terus bertambah.

Untuk indikator orang merupakan indikator yang dapat memberikan kontribusi terhadap minat masyarakat Bawean dalam memilih Bank Mitra Syariah. Pegawai ketika terampil dan sopan dalam melayani masyaarkat itu merupakan suatau hal yang luar biasa. Karena hal tersebut dapat memberikan kenyamanan terhadap nasabah, dan besar kemungkinan Bank Mitra Syariah akan bertambah nasabahnya.

Promosi merupakan indikator yang dapat memberikan kontribusi terhadap minat masyarakat Bawean dalam memilih Bank Mitra Syariah. Karena untuk mengetahui kegiatan dan produk apa saja yang ada pada Bank Mitra Syariah terdapat pada Brosur, semakin menarik dan lengkap isi brosur tersebut minat masyarakat Bawean dalam memilih Bank Mitra Syariah semakin besar.

Demikian juga lokasi merupakan indikator yang dapat memberikan kontribusi terhadap minat masyarakat Bawean dalam memilih Bank Mitra Syariah. Semakin lokasi itu mudah untuk diakses dan dekat dengan keramaian masyarakat Bawean maka semakin banyak masyarakat Bawean yang akan menabung di Bank Syariah.

Sedangkan harga merupakan indikator yang dapat memberikan kontribusi terhadap minat masyarakat Bawean dalam memilih Bank Mitra Syariah. Sangat penting dalam penentuan harga menggunakan prinsip syariah, karena segala sesuatu yang di hubungkan dengan prinsip syariah akan memberikan keunggulan tersidiri, dan hal tersebut terbukti dengan adanya minat masyarakat Bawean dalam memilih Bank Mitra Syariah.

Indikator bukti fisik merupakan indikator yang dapat memberikan kontribusi terhadap minat masyarakat Bawean dalam memilih Bank Mitra 
Syariah. sarana parkir yang disediakan oleh pihak Bank Mitra Syariah sangat memadai dan aman, sehingga hal tersebut bisa memberikan kenyamanan terhadap masyarakat Bawean sebelum memasuki kantor.

\section{Faktor Internal Individu Konsumen yang Mempengaruhi Minat Masyarakat Bawean dalam Memilih Bank Mitra Syariah}

Indikator Persepsi merupakan indikator yang dapat memberikan kontribusi terhadap minat masyarakat Bawean dalam memilih Bank Mitra Syariah. Akad-akad yang dilakukan oleh Bank Mitra Syariah tersebut menggunakan perinsip syariah dan membuat mereka tertarik dan memiliki minat untuk menjadi nasabah di Bank Mitra Syariah, karena dengan berpegang teguh pada perinsip syariah tidak diragukan lagi keabsahannya (kemakmuran dunia dan akhirat).

Motivasi merupakan indikator yang dapat memberikan kontribusi terhadap minat masyarakat Bawean dalam memilih Bank Mitra Syariah. Ada dorongan yang dapat memenuhi kebutuhan yang diinginkan oleh para masyarakat Bawean untuk memilih Bank Mitra Syariah. Salah satunya yaitu prinsip bagi hasil secara islami merupakan salah satu hal yang diminati oleh para masyarakat Bawean.

Pembelajaran merupakan indikator yang dapat memberikan kontribusi terhadap minat masyarakat Bawean dalam memilih Bank Mitra Syariah. pengetahuan yang dimiliki oleh masyarakat dengan akad yang diterapkan pada Bank Mitra Syariah merupakan proses intraksi dengan pegawai, dimana adanya pengetahuan tersebut bisa membantu meyakinkan pada masyarakat Bawean dan mempermudah masyarakat Bawean dalam melakukan intraksi dengan pegawai Bank Mitra Syariah.

Selain itu kepribadian juga merupakan indikator yang dapat memberikan kontribusi terhadap minat masyarakat Bawean dalam memilih Bank Mitra Syariah. Lingkungan yang berada pada masyarakat dapat mempengaruhi minat masyarakat Bawean dalam memilih Bank Mitra Syariah.

Sikap merupakan indikator yang tidak dapat memberikan kontribusi terhadap minat masyarakat Bawean dalam memilih Bank Mitra Syariah. Karena jika belum memberikan kepusan terhadap masyarakat Bawean. salah satunya yaitu transaparan dalam bagi hasil belum memberikan kepuasan dan belum mempengaruhi minat masyarakat Bawean dalam memilih Bank Mitra Syariah. 
Faktor Eksternal Individu Konsumen yang Mempengaruhi Minat Masyarakat Bawean dalam Memilih Bank Mitra Syariah

Referensi kelompok merupakan indikator yang dapat memberikan kontribusi terhadap minat masyarakat Bawean dalam memilih Bank Mitra Syariah. Selain mengacu pada salah seorang tokoh yang dipercaya dalam mengambil kebijakan untuk mengambil keputusan, mereka juga melihat pada lingkungan yang ada disekitarnya untuk mengambil keputusan, karena lingkungan yang ada disekitarnya merupakan lingkungan yang islami, maka ada kemungkinan besar masyarakat Bawean mempunyai minat untuk memilih Bank Mitra Syariah.

Status sosial merupakan indikator yang dapat memberikan kontribusi terhadap minat masyarakat Bawean dalam memilih Bank Mitra Syariah. Adanya Bank Mitra Syariah disekitar masyarakat dapat membantu merubah gaya hidup masyarakat ke yang lebih islami, dan mereka tidak hanya beragama islam akan tetapi juga melakukan kegiatan yang bernuansa islami.

Budaya merupakan indikator yang dapat memberikan kontribusi terhadap minat masyarakat Bawean dalam memilih Bank Mitra Syariah. Kegiatan yang ada pada bank tersebut sesuai dengan ajaran islam, sehingga mereka meyakini bahwasanya kegiatan yang ada sudah sesuai dengan agama yang mereka yakini dan mereka tidak ragu sedikitpun karena ajaran yang mereka ikuti adalah akan membawa berkah dimasa depannya.

Keluarga merupakan indikator yang tidak dapat memberikan kontribusi terhadap minat masyarakat Bawean dalam memilih Bank Mitra Syariah. Ada beberapa masyarakat Bawean yang menyatakan bahwa memilih Bank Mitra Syariah bukan dari siapa-siapa termasuk bukan dari keluarga, akan tetapi itu muncul dari dalam diri mereka sendiri untuk menabung di Bank Mitra Syariah, karena itu adalah kebutuhan mereka sendiri bukan kebutuhan orang lain.

\section{Strategi Pemasaran Untuk Meningkatkan Minat Masyarakat Bawean dalam memilih Bank Mitra Syariah}

Faktor marketing mix merupakan faktor yang paling dominan dalam memberikan kontribusi terhadap minat masyarakat Bawean dalam memilih Bank Mitra Syariah. Seorang marketing perbankan syariah dalam menjalankan tugasnya sebagai penggali dana masyarakat (funding) dan menyalurkan kemabali dana tersebut lewat pembiayaan (lending) harus berdasarkan prinsip syariah.

Menurut (Peter, et al., 2013) strategi pemasaran yaitu sebuah alat atau desain untuk mempengaruhi pertukaran demi mencapai pertukaran organisasi. Stragi pemasaran yang akan dilakukan bertujuan untuk memperolah atau menghasilkan sesuatu yang maksimal. Terdapat beberapa 
stategi pemasaran yang dapat dilakukan oleh Bank Mitra Syariah, yaitu : Pertama, Bank Mitra Syariah dapat menetapkan segmentasi pasar keseluruh masyarakat Bawean.Selain itu, juga harus melakukan sosialisasi secara menyeluruh agar masyarakat Bawean punya pengetahuan terhadap Bank Syariah khususnya Bank Mitra Syariah. Sosialisasi tersebut dapat dilakukan di seluruh sekolah-sekolah atau komonitas yang ada di desa-desa di pulau Bawean. Kedua, Bank Mitra Syarih melakukan jembut bola khususnya pada masyarakat yang sudah menjadi nasabah pada bank mitra syariah, kegiatan ini sangat efektif karena dapat memberikan kenyamanan terhadap masyarakat yang sudah menjadi nasabah. Selain itu, kegiatan nasabah tersebut juga tidak terganggu ketika akan melakukan simpanan di bank mitra syariah dan tidak mengharuskan mereka datang langsung kekantor bank mitra Syariah. Ketiga, masyarakat Bawean punya hobi mengoleksi emas khususnya para ibu-ibu. Ketika menghadiri acara resepsian atau bepergian kepasar atau jalan-jalan biasanya para ibu-ibu memakainya secara berlebihan. Ini merupakan salah satu potensi yang dapat dimanfaatkan oleh bank mitra syariah untuk meningkatkan dari sektor lending.

\section{KESIMPULAN}

Melalui analisis faktor yang telah dilakukan terdapat 3 faktor dan setiap faktor terdapat beberapa indikator yang dapat memberikan kontribusi terhadap minat masyarakat Bawean dalam memilih Bank Mitra Syariah. Faktor pertama yaitu marketing mix. Pada faktor ini terdapat 7 indikator yang dapat memberikan kontribusi terhadap minat masyarakat Bawean dalam memilih Bank Mitra Syariah yaitu: proses, produk, orang, promosi, lokasi, harga, dan bukti fisik. Faktor kedua yaitu faktor internal individu konsumen. Pada faktor ini terdapat indikator persepsi, motivasi, pembelajaran, dan pembelajaran yang dapat memberikan kontribusi terhadap minat masyarakat Bawean dalam memilih Bank Mitra Syariah. Sedangkan indikator sikap tidak dapat memberikan kontribusi terhadap minat masyarakat Bawean dalam memilih Bank Mitra Syariah. Faktor ketiga yaitu eksternal individu konsumen. Pada faktor ini terdapat indikator referensi kelompok, status sosial, dan budaya yang dapat memberikan kontrisbusi terhadap minat masyarakat Bawean dalam memilih Bank Mitra Syariah. Sedangkan indikator keluarga tidak dapat memberikan kontribusi terhadap minat masyarakat Bawean dalam memilih Bank Mitra Syariah.

Terdapat 3 faktor yang mempengaruhi minat masyarkat Bawean dalam memilih Bank Mitra Syariah, akan tetapi terdapat satu faktor yang paling dominan yaitu faktor marketing mix. Pada faktor marketing mix paling indikator yang paling dominan yaitu indikator proses. Pada fator internal 
individu konsumen indikator yang paling dominan yaitu indikator persesi. Dan faktor eksternal individu konsumen indikator yang paling dominan yaitu indikator referensi kelompok.

Bagi pihak Bank Mitra Syariah lebih memperhatikan lagi aspek faktor marketing mix untuk mengembangkan dan kemajuan Bank Mitra Syariah di kalangan masyarakat Bawean. Karena faktor marketing mix merupakan faktor yang paling dominan pada penelitian di atas. Bagi peneliti selanjutnya diharapkan dapat mengembangkan dari hasil penelitian ini, dan diharapkan dapat menggunakan variabel atau indikator yang berbeda, sehingga mampu untuk menghasilkan temuan yang baru dan tajam untuk menyempurnakan penelitian ini. Bagi masyarakat diharapkan tidak takut dengan sesuatu hal yang baru dan belum diketahui apa yang ada disekitarnya. supaya tidak salah mengambil keputusan masyarakat harus mencari informasi mengenai hal yang baru supaya dapat melakukan pilihan untuk memenuhi kebutuhannya. tidak menutup kemungkinan suatu hal yang baru tersebut jika dikaji secara baik dapat memberikan manfaat dan menguntungkan dimasa yang datang.

\section{DAFTAR PUSTAKA}

Asyhar, A. (2017). Model Transformasi Pendidikan Pondok Pesantren di Pulau Bawean (Studi Multi Kasus di Pondok Pesantren Hasan Jufri, Mambaul Falah dan Nurul Ikhlas (Disertasi). Surabaya: Universitas Islam Negeri (UIN) Sunan Ampel.

Blut, M., Teller, C., \& Floh, A. (2018). Testing Retail Marketing-Mix Effectson Patronage: A Meta-Analysis. Journal of Retailing , 113-135.

Engel, J. B. (1994). Prilaku Konsumen. Jakarta : Binapura Aksara.

Engel, J., Blackwell, R., \& Miniard , P. (1994). Prilaku Konsumen. Jakarta : Binapura Aksara.

Fitriyani, Y. (2016). Analisis Faktor-Faktor yang Mempengaruhi Pengambilan Keputusan Nasabah Memilih Bank Syariah di Kecamatan Ciputat (Skripsi). Jakarta: Fakultas Ilmu Tarbiyah dan Keguruan Universitas Islam Negeri Syarif Hidayatullah Jakarta.

Fortrania, L. M., \& Oktaviana, U. K. (2015). Analisis Tingkat Kesehatan Bank Umum Syariah dan Unit Usaha Syariah dengan Metode CAMELS dan RGEC. El Dinar: Jurnal Keuangan dan Perbankan Syariah , 118-126.

Jannah, N. (2010). Analisis Faktor-Faktor yang Mempengaruhi Keputusan Konsumen dalam Menggunakan Ponsel GSM Tipe QWERTY (Pada konsumen Ponsel GSM Tipe QWERTY di Kecamatan Kebayoran Lama Jakarta Selatan (Skripsi). Jakarta: Fakultas Ekonomi dan Bisnis Universitas Islam Negeri Syarif Hidayatullah Jakarta.

Kasmir. (2008). Pemasaran Bank. Jakarta: Kencana. 
Mufidah, N., \& Purnamasari, P. E. (2018). Pengaruh Profitabilitas Terhadap Nilai Perusahaan dengan Pengungkapan Corporate Social Responsibility dan Good Corporate Governance sebagai Variabel Moderating. El Dinar: Jurnal Keuangan dan Perbankan Syariah, 64-82.

Nelvi, N. (2015). Faktor-Faktor yang Mempengaruhi Keputusan Nasabah dalam Memilih Bank Syariah (Studi Kasus pada Nasabah BNI Syariah Yogyakarta) (Skripsi). Yogyakarta: Fakultas Syariah dan Hukum Universitas Islam Negeri Sunan Kalijaga Yogyakarta.

Nitisusastro, M. (2012). Prilaku Konsumen dalam Prespektif Kewirausahaan. Bandung: Alfabeta.

Peter, J. P., \& Olson, J. C. (2013). Consumer Behavior Perilaku Konsumen dan Strategi Pemasaran. Jakarta: Erlangga.

Purboyo, \& Huda, N. (2017). Pengaruh Eksternal, Internal dan Gaya Hidup Terhadap Keputusan Pembelian Sepeda Motor di Banjarmasin. Jurnal Wawasan Manajemen , 175-188.

Rivai, V., \& Arivin, A. (2010). Islamic Banking : Sebuh Teori, konsep, dan aplikasi. Jakarta: Bumi Aksara.

Sartono, G., Susanti, R., \& Lamidi. (2018). Pengaruh Perceived Quality, Inovasi, Kelompok Referensi, Dan Celebrity Endorser Terhadap Keputusan Pembelian Sepatu Sepak Bola Merek Nike. Jurnal Ekonomi dan Kewirausahaan , 429 - 440.

Schiffman, L., \& Kanuk, L. (2008). Prilaku Konsumen. Klaten: PT Macanan Jaya Cemerlang.

Simamora, B. (2004). Panduan Riset Perilaku Konsumen. Jakarta: PT Gremadia Pustaka Utama.

Utomo, T. P. (2014). Analisis Faktor-Faktor yang Mempengaruhi Keputusan Nasabah dalam Memilih Jasa Perbankan Syariah (Studi pada Bank Syariah Mandiri Kantor Cabang Malang) (jurnal Ilmiah). Malang: Fakultas Ekonomi dan Bisnis. 